\title{
First observation of the zebra mussel (Dreissena polymorpha (Pallas, 1771)) on the narrow-clawed crayfish inhabiting in some water sources of Turkey
}

\section{Zebra midyesinin (Dreissena polymorpha'nın (Pallas, 1771)) Türkiye'nin bazı su kaynaklarında yaşayan dar kıskaçlı kerevitler üzerinde ilk olarak gözlenmesi}

\author{
Selçuk Berber* (D) A. Suat Ateş (D) - Seçil Acar (D) \\ Çanakkale Onsekiz Mart University, Faculty of Marine Sciences and Technology 17100 Çanakkale, Turkey
}

${ }^{*}$ Corresponding author: selcukberber@comu.edu.tr

\section{How to cite this paper:}

Berber, S., Ateş, S. \& Acar, S. (2018). First observation of the zebra mussel (Dreissena polymorpha (Pallas, 1771)) on the narrow-clawed crayfish inhabiting in some water sources of Turkey. Ege Journal of Fisheries and Aquatic Sciences, 35(1): 55-61. doi:10.12714/egejfas.2018.35.1.10

\begin{abstract}
The zebra mussel, Dreissena polymorpha (Pallas, 1771) is considered as a harmful invasive epibiont species for hydroelectric and nuclear power plants as it reduces or blocks water flow in the plant systems. Although $D$. polymorpha is reported that it cleans the water, increases water visibility, and filters out pollutants, it has likewise negative impacts on the population and size of some fish and aquatic species. In the present study, zebra mussels were observed for the first time. On the narrow-clawed crayfish living in some water sources in Turkey. Specimens were collected from two natural lakes (Çıldır Lake, Eğirdir Lake) and five ponds (Altınyazı Dam Lake, Keban Dam Lake, Küçükçekmece Lake, Karpuzlu Dam Lake, Kadıköy Dam Lake) in Turkey. Attachments of the zebra mussel to the different body parts of the narrow-clawed crayfish were documented in the present study. Cochran's $Q$ test results showed that the numbers of mussels clinging to the different parts of the crayfish varied $(P=0.000)(P<0.001)$. The difference between the holding regions of zebra mussels on crayfish specimens may cause some adverse effects on the host. Particularly the intensive grip on the carapace partially obstruct the movement, feeding, mating, avoiding predators, and shelter. mussel individuals in the pleopodal region may have difficulty holding and transporting eggs. This study is the first report about the occurrence of $D$. polymorpha on Astacus leptodactylus in Turkish waters.
\end{abstract}

\section{Keywords: Dreissena polymorpha, Zebra mussel, Astacus leptodactylus, body colonization, Turkey}

Öz: Zebra midyeleri, Dreissena polymorpha (Pallas, 1771) hidroelektrik ve nükleer güç sistemlerinde su akışını engellediğinden zararlı bir istilacı epibiont türü olarak kabul edilir. $D$. polymorpha suyun temizlenmesi, su görünürlüğünün arttırılması ve kirleticilerin filtrelenmesi olarak rapor edilmesine rağmen, bazı balıkların ve sucul türlerin popülasyonu ve büyüklüğü üzerinde olumsuz etkilere sahiptir. Bu çalışmada, zebra midyesi Türkiye'deki bazı su kaynaklarındaki tatısu ıstakozu üzerinde ilk defa gözlemlenmiştir. Bireyler Türkiye'deki iki doğal göl (Çıldır Gölü, Eğirdir Gölü) ve beş göletten (Altınyazı Baraj Gölü, Keban Baraj Gölü, Küçükçekmece Gölü, Karpuzlu Baraj Gölü, Kadıköy Baraj Gölü) toplanmıșı. Bu çalıșmada, kerevitlerin farklı vücut bölümlerine zebra midyesinin tutunması belgelenmiştir. Cochran's $Q$ test sonuçları; kerevitin değişik bölümlerine tutunan midye sayılarının farklılık gösterdiğini ortaya koydu $(P=0.000)(P<0.001)$. Zebra midyelerin tatlısu ıstakozlarının üzerinde tutunma bölgeleri arasında farklıı̆ın tespit edilmesinin konakçı açısından bazı olumsuzluklara neden olabileceği düşünülmektedir. Özellikle carapax bölgesinde yoğun tutunmaların; hareket (beslenme, çiftleşme, predatörlerden kaçınma ve barınma). Pleopodal bölgedeki midye bireyleri ise yumurta tutunumu ve taşınımını zorlaşııabilir. Bu çalışma Türkiye sularındaki Astacus leptodactylus üzerinde Dreissena polymorpha'nın varlığı ile ilgili ilk rapordur.

Anahtar kelimeler: Dreissena polymorpha, Zebra midyesi, Astacus leptodactylus, vücut kolonizasyonu, Turkey

\section{INTRODUCTION}

Invasions and their negative impact on native communities are considered as important threats to biodiversity (Geiger et al. 2005). Invasive species may change the behavior and habitat use of native species. Population structure, distribution and abundance of the species are affected by invasive species (Simon and Townsend, 2003). Zebra mussel, Dreissena polymorpha (Pallas, 1771) is an invasive Ponto-Caspian bivalve and has invaded the European's river and channel (c) Published by Ege University Faculty of Fisheries, Izmir, Turkey systems during the last two centuries (Gonçalves et al. 2013). It has been introduced to the northwestern Russia, the southern Scandinavia, Britain, Ireland and the north America (Gonçalves et al. 2013; Minchin and Rosenthal, 2002) and found the east into the western Asia and the south into Turkey (Mackie et al. 1989). These invasions cause dramatic changes on benthic ecology and have both negative and positive effects on benthic ecosystem. Zebra mussel increases colonies of gastropod, but 
limits their body size. D. polymorpha has positive effect on deposit feeding taxa and negative effect on filter-feeding taxa (Ward and Ricciardi 2007).

Environmental and anthropogenic factors affect the spread of $D$. polymorpha in a new area. Water quality, alkalinity and high levels of calcium in fresh water increase the populations of zebra mussel juveniles. The levels of $\mathrm{pH}$, temperature, and potassium in water positively affect colonization and population structure of the zebra mussel (Stier et al. 2001). The narrowclawed crayfish, Astacus leptodactylus is a suitable substrate for the settlement of fouling organisms. Livings such as cyanobacteria and chlorophyta, ciliata, corixid eggs, mites, ostracods, oligochaetes, polychaetes, rhabdocoel flatworms, rotifers, Argulus eggs, bryozoans, and zebra mussels are settle down on crusts of freshwater crayfish (Alderman and Polglase 1988; Amato, 2001; Brazner and Jensen 2000; Cannon and Jennings 1987; Ďuriš et al. 2007; Edgerton et al. 2002; Lamanova, 1971; Romero and Jiménez 2002; Morado, 1995 Harlıoglu, 1999; Sprague and Couch, 1971; Şaşı and Berber, 2005; Quaglio et al. 2006). The zebra mussels modify the natural movement of crayfish and they may affect the anthropogenic structure (Ahne, 1985; Feist et al. 2001; Molloy et al. 1997; Mühlegger et al. 2009). Due to the zebra mussels are colonized on crayfish, the specimens of crayfish spend more energy. These factors (feeding, nursing, mating, molting etc.) lead to a reduction in life chances (Brazner and Jensen 2000). This study was aimed to describe the effects of microhabits on the crusts of $A$. leptodactylus specimens found in two lakes and five dam lakes in Turkey.

\section{MATERIALS AND METHODS}

\section{Sampling stations}

A total of 228 specimens of $A$. leptodactylus were collected August 2009 - December 2009 from two lakes (Eğirdir Lake

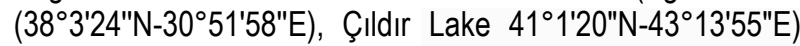
and five dam lake (Altınyazı Dam Lake $\left(41^{\circ} 3^{\prime} 28^{\prime \prime} \mathrm{N}\right.$ $\left.26^{\circ} 35^{\prime} 27^{\prime \prime E}\right)$, Keban Dam Lake (3850'39"N-39¹0'30"E), Küçükçekmece Lake (41000'59"N-28074'89"E), Karpuzlu Dam Lake $\left(40^{\circ} 49^{\prime} 58^{\prime \prime N}-26^{\circ} 17^{\prime} 38^{\prime \prime E}\right)$, Kadıköy Dam Lake $\left(40^{\circ} 47^{\prime} 38^{\prime \prime} \mathrm{N}-26^{\circ} 46^{\prime} 26^{\prime \prime E}\right)$ ) located of Turkey. Crayfish specimens were sampled using the single-entry two pints fyke nets of $34 \mathrm{~mm}$ mesh size by researchers. Sampled crayfish were separated to sex. Then, the body parts of crayfish were divided according to the zebra mussel's attachment. The zebra mussels were observed in the different parts of crayfish were photographed. It was observed whether the individuals of $D$. polymorpha removed from holding parts caused any damage on crusts of $A$. leptodactylus specimens. All crayfish specimens with the zebra mussels were proportionally recorded. Cochran $\mathrm{Q}$ test and MDS (Multidimensional Scaling Analysis) were applied to determine the chances in the cling aspects of $D$. polymorpha on the crusts of $A$. leptodactylus.

The $Q$ statistic is distributed approximately as chi- square with (a-1) degree of freedom (Zar, 1999).

\section{Cochran Q-test:}

Test statistic for Cochran $Q$ test:

$$
Q=\frac{(a-1)\left(\sum_{i=1}^{a} G_{i}^{2}-\frac{\left.\left(\sum_{i=1}^{a} G_{i}\right)\right]^{2}}{a}\right)}{\sum_{j=1}^{b} B_{j}-\frac{\sum_{j=1}^{b} B_{j}^{2}}{a}}
$$

Where; $a$ is the number of group, $b$ is the number of block, $\mathrm{Gi}$ is the sum of the 1's in group I, Bj is the sum of the 1's in block j

\section{RESULTS}

A total of 228 individuals of crayfish individuals were captured from the different locations in Turkey. The body length range of the crayfish was between 99.28 and $146.14 \mathrm{~mm}$. The mean body length of the crayfish is $138.02 \pm 2.063 \mathrm{~mm}$ in Altınyazı Dam Lake, $118.2 \pm 4.56 \mathrm{~mm}$ in Keban Dam Lake, $129.06 \pm 5.68 \mathrm{~mm}$ in Çıldır Lake, $115.28 \pm 1.61 \mathrm{~mm}$ in Küçükçekmece Lake, $116.39 \pm 4.44 \mathrm{~mm}$ in Eğirdir Lake, $133.46 \pm 2.68 \mathrm{~mm}$ in Karpuzlu Dam Lake and $125.72 \pm 2.61 \mathrm{~mm}$ in Kadıköy Dam Lake. Although the zebra mussels prefer the different body parts of crayfish, the carapace is the most attached part with a ratio of $25.6 \%$. Totally, 28 specimens of the zebra mussel were observed on the carapace. The lowest rate $(0.73 \%)$ was recorded on the oviducts of crayfish. Only one individual clung to the oviduct. The body lengths of $D$. polymorpha specimens clunged to the bodies of crayfish are mostly less than $5 \mathrm{~mm}$ (Table 1).

Table 1. The body part preference on the body of crayfish by $D$. polymorpha.

\begin{tabular}{|c|c|c|c|c|c|c|c|c|c|c|c|c|c|}
\hline Sampling sites & $\mathrm{N}$ & $\mathbf{N}^{\prime}$ & $M$ & $\mathbf{F}$ & C & $\mathbf{R}$ & $A D$ & $\mathrm{CV}$ & An & CD & $\mathrm{T}$ & $\mathbf{P}$ & 0 \\
\hline Altınyazı Dam Lake & 18 & 3 & 3 & - & 1 & 1 & 1 & 1 & 0 & 2 & 1 & 1 & 0 \\
\hline Keban Dam Lake & 51 & 3 & 3 & - & 1 & 0 & 0 & 0 & 1 & 3 & 0 & 1 & 0 \\
\hline Çıldır Lake & 34 & 3 & 3 & - & 2 & 1 & 1 & 0 & 1 & 1 & 0 & 1 & 0 \\
\hline K.Çekmece Dam Lake & 26 & 12 & 2 & 10 & 5 & 5 & 5 & 0 & 4 & 8 & 7 & 0 & 0 \\
\hline Eğirdir Lake & 48 & 1 & - & 1 & 1 & 1 & 0 & 0 & 1 & 0 & 0 & 0 & 0 \\
\hline Karpuzlu Dam Lake & 24 & 13 & 10 & 3 & 3 & 1 & 3 & 2 & 0 & 3 & 6 & 10 & 0 \\
\hline Kadıköy Dam Lake & 27 & 14 & & 9 & 4 & 0 & 7 & 4 & 1 & 11 & 1 & 0 & 1 \\
\hline$\overline{\text { Total }}$ & 228 & 49 & 26 & 23 & 17 & 9 & 17 & 7 & 8 & 28 & 15 & 13 & 1 \\
\hline
\end{tabular}

$\mathrm{N}$ : number of crayfish examined, N': number of crayfish carrying $D$. polymorpha, M: Male, F: Female, C: Chela, R: Rostrum, AD: Abdomen, CV: Carapace ventral, An: Antenna, CD: Carapace dorsal, T: Telson, P: Pleiopod, O: Oviduct 
Crayfish specimens show reactions with respect to the change of the body regions invaded by the zebra mussels (Fig. 3). Holding locations on the crayfish by the zebra mussels are no accidental for both sexes of $A$. leptodactylus. According to the results of the MDS analysis, sexuel difference in crayfish have a decisive effect about holding of zebra mussels. The body length of crayfishes in both sexes is decisive in choosing the region to be attached by $D$. polymorpha (Fig. 1, 2).

\section{Derived Stimulus Configuration}

\section{Euclidean distance model}

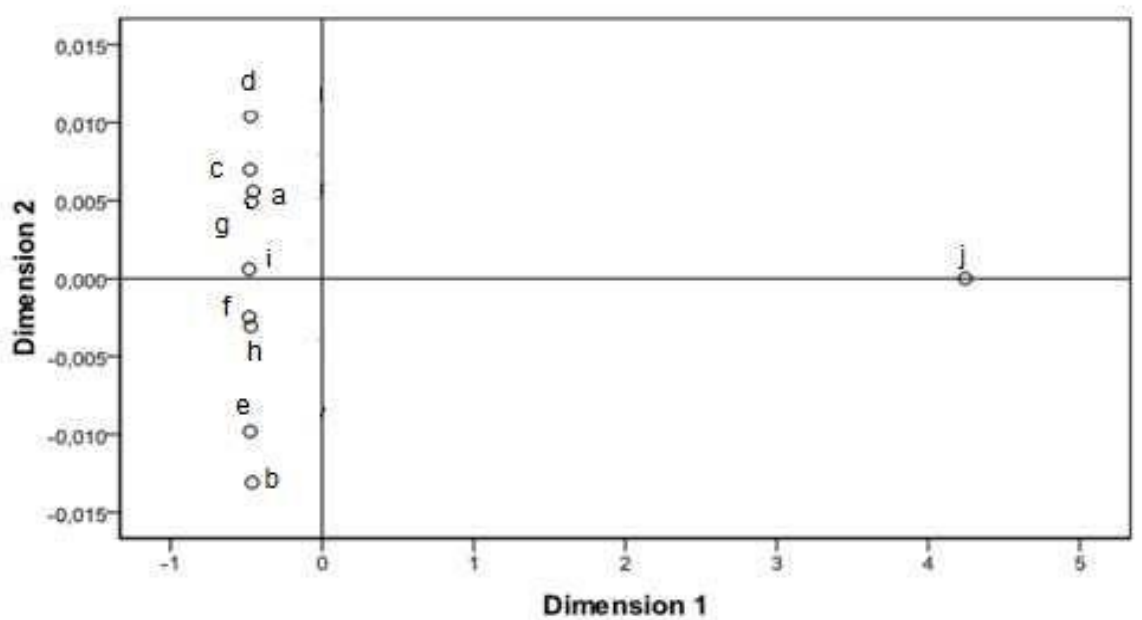

Figure 1. Multidimensional scaling analysis for female crayfish, a: carapace dorsal, b: abdomen, c: antenna, d: rostrum, e: carapace ventral, f: oviduct. g: chela, h: telson, l: pleopod; j: length.

\section{Derived Stimulus Configuration}

\section{Euclidean distance model}

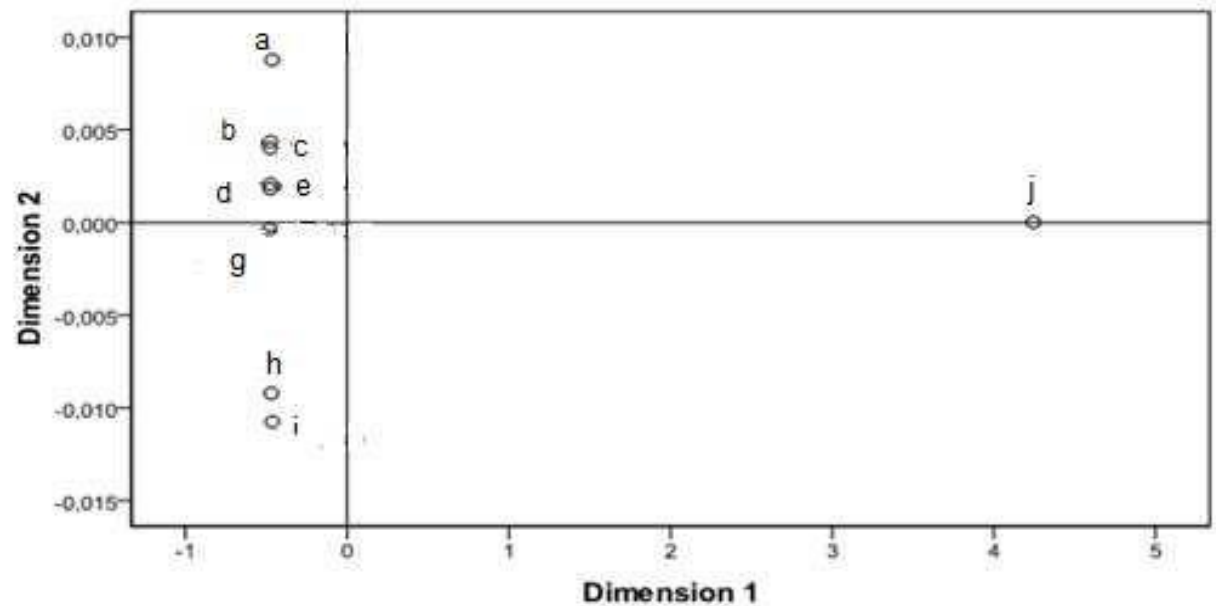

Figure 2. Multidimensional scaling analysis for male crayfish, a: carapace dorsal, b: abdomen, c: antenna, d: rostrum, e: carapace ventral, g: chela, h: telson, i: pleipod, j: length. 


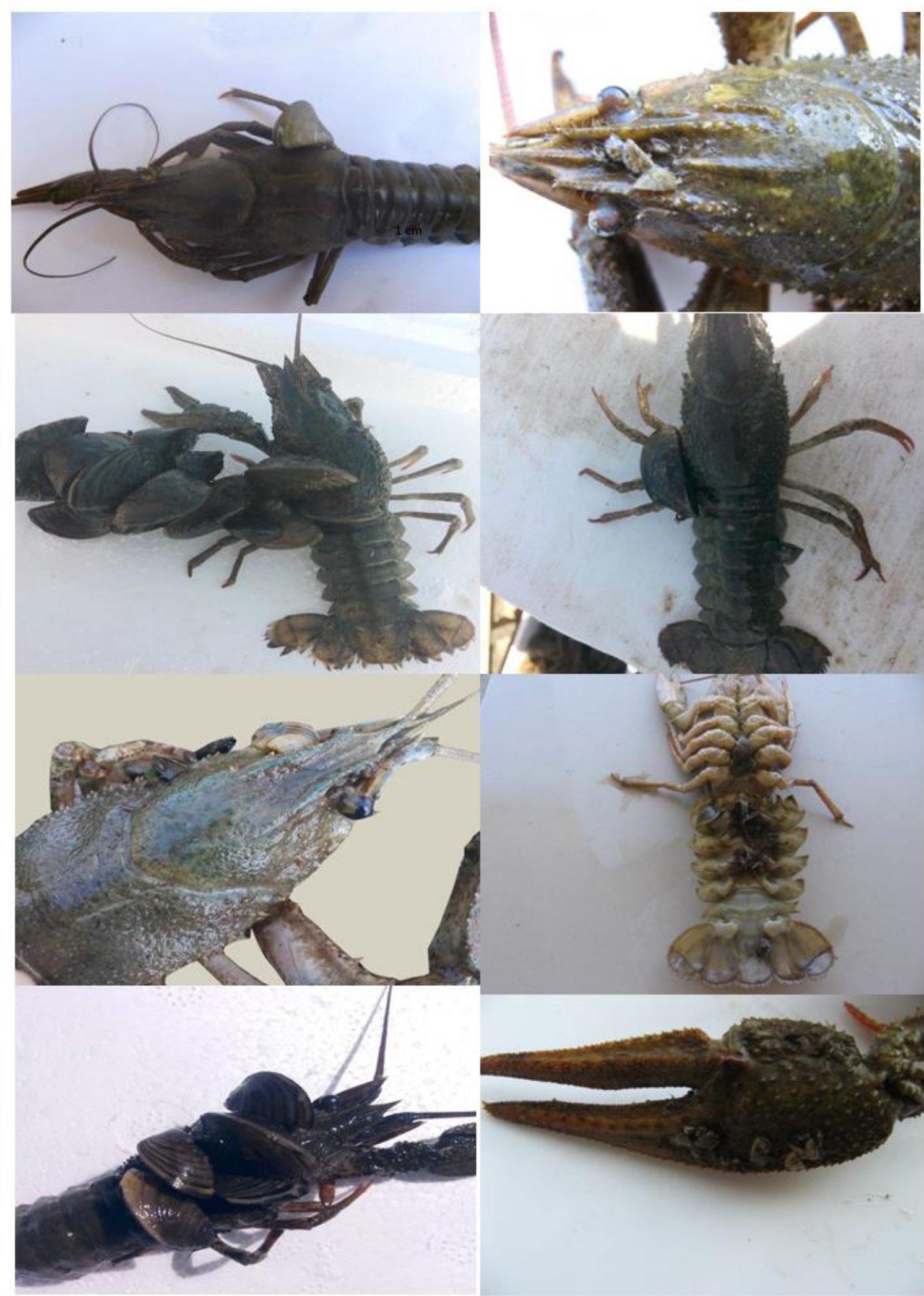

Figure 3. Zebra mussel specimens on the various body parts of crayfish, A. leptodactylus. (A, C, D, G: on carapace dorsal, B, E: on eyes, F: on carapace ventral and pleiopod, $\mathrm{H}$ : on cheliped) 


\section{DISCUSSION}

D. polymorpha composes dense populations on any available hard substrate. Its veliger larvae settles predominantly on shells or near older zebra mussels (Griffiths et al. 1989). The specimens of $D$. polymorpha can also settle on a crayfish exoskeleton (Rogers et al. 2003). The first observation of $D$. polymorpha as host on crayfish was given by Laurent and Suscillon (1962) from male specimens of $D$. polymorpha on 0 . limosus observed in France. This phenomenon was confirmed for the Lake of Geneva (Lac Léman) by Laurent (1994) on O. limosus. Lamanova (1971) reported the zebra mussels on crust of crayfish, Astacus leptodactylus cubanicus co-inhabiting to the original distribution area of the zebra mussel.

Smietana (1996) reported the occurrence of the zebra mussels on O. limosus in the Dabie Lake (Poland). Lajtner et al. (2005) reported the specimens of $D$. polymorpha attached to the carapace of crayfish, 0 . limosus in Croatia. While rare, a similar phenomenon has been observed in Lake Michigan (the North America) (Brazner and Jensen 2000) and the individuals of $D$. polymorpha occurred on the body of the rusty crayfish, Orconectes rusticus.

D. polymorpha was introduced to Czech waters via two directions (by the Danube and Morava rivers) (Beran, 2002). Petrusek et al. (2006) carried out a study on the invasion of $O$. limosus by $D$. polymorpha in about 60 localities of Czech Republic in 2003-2004. According to Petrusek et al. (2006), the carapace of specimens of crayfish were colonized by mussels and this manner shows that this phenomenon is rather rare. Besides, this unusual situation clarifies the lack of available hard substrates for larval veliger settlement, although other environmental variables such as nutrients, water temperature, and chemistry measured are optimal for the zebra mussel population. The high calcium ion concentration, $\mathrm{pH}$, summer temperatures up to $25^{\circ} \mathrm{C}$, absence of spring algal bloom and round-year clean water indicate moderate tropic relations. All these environmental variables are well comparable with existing knowledge on $D$. polymorpha requirements (McMahon, 1996; Bowman et al. 1998; Toomay et al. 2002).

The microhabitats used by the zebra mussel for colonization are interesting. Brazner and Jensen (2000) refer that $D$. polymorpha mostly colonized the carapace of 0 . rusticus rather than the parts of the body such as chelae, telson, and uropod. Duuriš et al. (2007) reported that the mussel specimens of one-year old were concentrated mainly on the anterior dorsal surface of the abdomen, although some remained on both the ventral abdomen and telson, and the anterior dorsal of cephalothorax.

Due to the zebra mussels colonize on crayfish, crayfish specimens spend more energy. Besides, crayfish can be easily recognized by the predators (Brazner and Jensen 2000). Moreover, $D$. polymorpha clinked to the different parts of crayfish inhibit the movement, sight, prey capture, reproduction, and molting ability (Lamanova, 1971; Bauer, 1989; Brazner and Jensen 2000).

This study showed that the females of crayfish invaded by D. polymorpha specimens have no fertilized eggs and this is another negative effect. On the other hand, the zebra mussels prefer especially the bodies of crayfish on soft-bottoms (Duriš et al. 2007). Thus, due to erosion in inland water resources the bottom structure change and it can be soft (Quinn and Janssen 1989).

Toomey et al. (2002) reported that the small $(5-10 \mathrm{~mm})$ specimens (\%55 of total population) of the zebra mussel are more navigate in their environment when compared to bigger individuals (10-20 mm). Toomey et al. (2002) concluded that the reason of this is the small mussels produce the smaller byssus and these small specimens leave more often from their substrate. In the present study it was recorded that the most of $D$. polymorpha clinked to crayfish in this study are small.

According to previous studies, the most of $D$. polymorpha attached to the crayfish had a length that is less than $5 \mathrm{~mm}$ and these specimens were younger than 1 year old (Ackerman et al. 1994; Ďuriš et al. 2007)

When the regional distributions of the species are considered approximately $50 \%$ of crayfish captured in Kadıköy Dam Lake, Karpuzlu Dam Lake, and Küçükçekmece Dam Lake have zebra mussels on them. Due to intensive fisheries activities in the areas cited, we think that larvae of Zebra mussels may be transported to near lake systems by fishing gears. In Turkey, transport of fishing gears used in inland water fishery is frequently observed between the lakes, ponds and reservoirs. This manner facilitates the transport of many disease agents and fouling organisms between locations. Also, uncontrolled fish and freshwater lobster infestations can cause similar results. Especially Dreissena polymorpha can stay alive for a long time outside of water (Altınayer et al., 2001). In particular, the research and fishing activities carried out by fishermen in the areas close to each other in Thrace Region have facilitated the transport of Dreissena polymorpha.

Our statistical results shows, that difference of holding regions on crayfish specimens is so important, regarding the cling ability of the mussels on the body parts of the crayfish. Furthermore, the clinging regions of the mussels on the crayfish's body sections are no accidental. The females of crayfish exhibit mostly the keeping behavior during their nest periods and are less active. Therefore, the zebra mussels have a better hold to the female crayfish. Differences between the sticking places of the zebra mussels were also observed (Duris et al., 2007). Duriš et al. (2007) stated that these differences are based on the parts cited are easily cleaned by individual crayfish.

Although the zebra mussels are consumed by crayfish, they have many unfavorable effects on crayfish. Consequently, the similar studies on invasion of Zebra mussel in various 
geographical areas of Turkey should be carried out to have more detailed information on the subject in future.

Studies on its distribution and invasion should be increased to have more information about ecological effects of Dreissena polymorpha. In DNA studies, the origins, differences and similarities of the populations at locations can be determined (Rohfritsch et al., 2013). Recently, it has been determined which populations are present in geographical areas invaded by $D$. polymorpha. In addition, it can be determined from which gene pool these populations are distributed (Lalias et al., 2015; Anglès d'Auriac et al., 2017).

Thanks to the results of such studies, more knowledge is available about limiting effects of characteristics such as growth and reproduction of Zebra mussels on crayfish populations and

\section{REFERENCES}

Ackerman J.D., Smith B., Nichols S.J. \& Claudi R. (1994). A review of the early life history of zebra mussels (Dreissena polymorpha): comparisons with marine bivalves. Canadian Journal of Zoology 72: 1169-1179. doi: 10.1139/z94-157.

Ahne W. (1985). Argulus foliaceus L. and Pisicola geometra L. as mechanica vectors of spring viremia of carp virus (SVCV). Journal of Fish Diseases 8:241-242.

Alderman D.J. \& Polglase J.L. (1988). Pathogens, parasites and commensals In: Holdich M, Lowery RS. (Eds.), Freshwater Crayfish: Biology. Management and Exploitation. Croom Helm, London 167-212.

Altınayar, G., Ertem, B., Aydoğan, F. (2001). Hidroelektrik Santrallar ve Su Arıtma Tesislerinde Sorun Yaratan Zebra Midye [Dreissena polymorpha (Pallas, 1771)] 'nin Yasamı ve Savaşımı. DSI Teknik Bülteni, Sayı: 98, 3339.

Amato J.F.R. (2001). A new species of Stratiodrilus (Polychaeta Histriobdellidae) from freshwater crayfishes of southern Brazil. Iheringia Série Zoologia 90:37-44. doi: 10.4067/S0717.

Anglès d'Auriac, M.B., Rinde, E., Norling, P., Lapègue, S., Staalstrøm, A. Hjermann, D.Ø., Thaulow, J., (2017). Rapid expansion of the invasive oyster Crassostrea gigas at its northern distribution limit in Europe: Naturally dispersed or introduced? PLOS ONE 12(5): e0177481. doi: $10.1371 /$.

Bauer R.T. (1989). Decapod crustacean grooming: functional morphology, adaptive value, and phylogenetic significance. Crustacean Issues 6:49-73

Beran L. (2002). Aquatic molluscs of the Czech Republic distribution and its changes, habitats, dispersal, threat and protection, Red List. Sbornik prirodovedneho klubu v Uherskem Hradisti, Supplementum 10: 258p.

Bowman M.F. \& Bailey R.C. (1998). Upper pH tolerance limit of the zebra mussel (Dreissena polymorpha). Canadian Journal of Zoology 76 (11): 2119-2123, doi: 10.1139/z98-155.

Brazner J.C. \& Jensen D.A. (2000). Zebra mussel [Dreissena polymorpha (Pallas)] colonization of rusty crayfish [Orconectes rusticus (Girard)] in Green Bay, Lake Michigan. American Midland. Naturalist 143:250-256. doi: 1674/0003-0031(2000)143[0250:ZMDPPC]2.0.CO;2.

Cannon L.R.G. \& Jennings J.B. (1987). Occurrence and nutritional relationships of four ectosymbiotes of the freshwater crayfish Cherax dispar Riek and Cherax punctatus Clark (Crustacea: Decapoda) in Queensland. Australian Journal of Marine\&Freshwater Research 38:419427.

Duriš Z., Horka I. \& Petrusek A. (2007). Invasive zebra mussel colonisation of invasive crayfish: a case study. Hydrobiologia 590: 43-46. doi: 10.1007/s10750-007-0755-x. interaction of species with each other. This present work deals with the presence of Zebra mussels on crayfish specimens.

\section{CONCLUSION}

Because of its role in the food chain, Dreissena polymorpha has positive effects on feeding, growing and population structure of many species. Yet, $D$. polymorpha is important to increase water clarity because of its filtration feature. Due to their high adaptation to environmental conditions and rapid reproduction, $D$. polymorpha specimens have very negative effects on other species in reservoirs. For that reason, an action plan on this species which causes billions of dollars of damage in the world should be prepared. Particularly, the methods (biological, chemical and physical) blocking the distribution of $D$. polymorpha should be determined. Furthermore, informative studies on reservoirs should be made.

Edgerton B.F., Evans L.H., Stephens F.J. \& Overstreet R.M. (2002). Synopsis of freshwater crayfish diseases and commensal organisms. Aquaculture 206:57-135, doi: 10.1016/S0044-8486(01)00865-1.

Feist S.W., Longshaw M., Canning E.U. \& Okamura B. (2001). Induction of proliferative kidney disease (PKD) in rainbow trout Oncorhynchus mykiss via the bryozoan Fredericella sultana infected with Tetracapsula bryosalmonae. Diseases of Aquatatic Organisms 45:61-68. doi: 10.3354/da0045061.

Geiger W., Alcorlo P., Baltanas A. \& Montes C. (2005). Impact of an introduced crustacean on the trophic webs of Mediterranean wetlands. Biological Invasions 7:49-73. doi: 10.1007/s10530-004-9635-8.

Gonçalves V., Rebelo R. \& Gherardi F. (2013). Fouling of invasive Red swamp crayfish, Procambarus clarkii (Girard, 1852) by the zebra mussel, Dreissena polymorpha (Pallas, 1771) in Lake Fouling of invasive Trasimeno, Italy. Aquatic Invasions 8(1): 117-120. doi: 10.3391/ai.2013.8.1.14

Griffiths R.W., Kovalak W.P. \& Schloesser D.W. (1989). The Zebra Mussel, Dreissena polymorpha (Pallas, 1997), in North America: Impact on Raw Water Users. In: EPRI Service Water System Reliability Improvement Seminar: Papers 11-27.

Harlıoglu M.M. (1999). The first record of Epistylis niagarae on Astacus leptodactylus in a crayfish rearing unit. Cip. Turkish Journal of Zoology 23:13-15.

Lajtner J., Klobucar G.I.V., Maguire I., Lucic A., Stambuk A. \& Erben R. (2005). They came from the Danube River-History and present status of Dreissena polymorpha and Orconectes limosus in Croatia, INWAT: Biological invasions in inland waters, Firenze, May 5-7, 42-43.

Lallias, D., Boudry, P., Batista, F.M., Beaumont, A., King, J.W., Turner, J.R., Lapègue, S., (2015). Invasion genetics of the Pacific oyster Crassostrea gigas in the British Isles inferred from microsatellite and mitochondrial markers. Biological Invasions, 17(9):2581-95.

Lamanova A.I. (1971). Attachment by zebra mussels and acorn barnacles on crayfish. Hydrobiology Journal 6: 89-91.

Laurent P.J. \& Suscillon M. (1962). Les ecrevisses en France, Annales de la Station Centrale d'Hydrobiologie Appliquee 9: 333-395.

Laurent P.J. (1994). Zebra Mussels on Crayfish, IAA Newsletter. 16 (4): 4-5.

Mackie E.J., Chiquet-Ehrismann R., Pearson C.A., Inaguma Y., Taya K., Kawarada Y. \& Sakakura T. (1989). Tenascin is a stromal marker for epithelial malignancy in the mammary gland. Proceedings of the National Academy of Sciences 84:4621-4625.

Mcmahon R.F. (1996). The physiological ecology of the zebra mussel, Dreissena polymorpha in North America and Europe. American Zoologist 36: 339-363 
Minchin D. \& Rosenthal H. (2002). Exotics for stocking and aquaculture, making correct decisions. In: Invasive aquatic species of Europe: distribution impacts and management. (eds) E. Leppakoski, S Gollasch, S. Olenin. Kluwer Academic Publishers Dordrecht 206-216.

Molloy D.P., Karatayev A.Y., Burlakova L.E., Kurandina D.P. \& Laruelle F. (1997). Natural enemies of zebra mussels: predators, parasites, and ecological competitors. Reviews in Fisheries Science 5: 27-97.

Morado J.F. (1995). Ciliate parasites and related diseases of Crustacea: a review. Reviews in Fisheries Science 3: 275-354.

Mühlegger M.J., Jirsa F., Konecny R., Sattmann H. \& Frank C. (2009). Bucephalus polymorphus Baer, 1827 - a new fish parasite in Austria? Wien Klin Wochenschr. 121: 50-52.

Petrusek A., Filipova L., Duris Z., Horka I., Kozak P., Policar T., Stambergova M. \& Kucera Z. (2006). Distribution of the invasive spiny-cheek crayfish (Orconectes limosus) in the Czech Republic. Past and present, Craynet, Bulletin Francais Pêche Pisciculture 4: 380-381:903-918. doi: 10.1051/kmae:2006030.

Quaglio F., Morolli C., Galuppi R., Tampieri M.P., Bonoli C., Marcer F., Rotundo G. \& Germinara G.S. (2006). Sanitary-pathological examination of red swamp crayfish (Procambarus clarkii Girard, 1852) in the Reno Valley. Freshwater Crayfish 15: 1-10.

Quinn J.P. \& Janssen J. (1989). Crayfish competition in southwestern Lake Michigan: a predator mediated bottleneck. Journal of Freshwater Ecology 5:75-85.

Rogers D., Hoffmann R. \& Oidtmann B. (2003). Diseases in selected Austropotamobius pallipes populations in England, In Holdich, D.M. Sibley, P.J., (eds), Management and Conservation of Crayfish, Proceedings of a conference, Nottingham Forest Footbal Club, 7 Nov., 2002, 169-174.

Rohfritsch, A., Bierne, N., Boudry, P., Heurtebise, S., Cornette, F., Lapègue S., (2013). Population genomics shed light on the demographic and adaptive histories of European invasion in the Pacific oyster, Crassostrea gigas. Evollutionary Application, 1064-1078.

Romero X. \& Jiménez R. (2002). Histopathological survey of diseases and pathogens present in redclaw crayfish, Cherax quadricarinatus (Von Martens), cultured in Ecuador. Journal of Fish Diseases 25:653-667. doi: 10.1046/j.1365-2761.2002.00411.x.

Şaşi H. \& Berber S. (2005). Prevalence of Epistylis sp. Ehrenberg, 1832 (Peritrichia, Sessilida) on the narrow-clawed crayfish, Astacus leptodactylus (Eschscholtz, 1823) from Manyas Lake in Turkey. Journal of Animal and Veterinary Advances 4(9): 789-793.

Simon K.S. \& Townsend C.R. (2003). Impacts of freshwater invaders at different levels of ecological organisation, with emphasis on salmonids and ecosystem consequences. Freshwater Biology 48: 982-994. doi: 10.1046/j.1365-2427.2003.01069.x.

Smietana P. (1996). Attachment of zebra mussel, Dreissena polymorpha (Pall.) to the exoskeleton of Orconectes limosus (Raf.) from the Dabie Lake, Przeglad Zoologiczny. 40(1-2): 69-72.

Sprague V. \& Couch J. (1971). An annotated list of protozoan parasites, hyperparasites, and commensals of decapod crustacea. Journal of Protozoology 18(3):526-537

Stier D., Leisenring M.A. \& Kennedy M.G. (2001). Identifying Potential Zebra Mussel Colonization. The UMAP Journal 22.4.

Toomey M.B., Mccabe D. \& Marsden J.E. (2002). Factors affecting the movement of adult zebra mussels (Dreissena polymorpha) Journal of North American Benthological Society 21 (3): 468-475.

Ward J.M. \& Ricciardi A. (2007). Impacts of Dreissena invasions on benthic macroinvertebrate communities: a metaanalysis. Diversity and Distributions, (Diversity Distrib.) 13:155-165. doi: 10.1111/j.1472-4642.2007.00336.x

Zar J.H. (1999). Biostatistical Analysis, Fourth Ed. Prentice Hall, New Jersey, USA. 